\title{
NPD IN SMALL MANUFACTURING ENTERPRISES IN SERBIA
}

\author{
Miloš Vorkapić, Filip Radovanović, Dragan Ćókalo, Dejan Đorđević
}

Professional paper

New product development in small manufacturing enterprises on the territory of Serbia was investigated on a representative sample of micro and small enterprises covering a broad range of businesses. It was found that market pull was the prevalent strategy for new product development, which was characterized by close collaboration with customers from the idea to the final product including the R\&D activities. Besides customers, the main sources of ideas were competitors and trade fairs or exhibitions. The marketing activities associated with new product introduction were quite limited. These findings were compared with new product development practices in neighboring countries. Based on our findings we propose two measures to improve new product development in small manufacturing enterprises in Serbia: establish a closer cooperation with external knowledge centers (universities, research institutes, innovation centers) and set up innovation networks with complementary partners by actively using the open innovation concept.

Keywords: idea sources; micro and small enterprises; new product development; open innovation

NPD u malim proizvodnim poduzećima u Srbiji

Stručni članak

Ispitivao se razvoj novog proizvoda (NPD - New Product Development) u malim proizvodnim poduzećima na području Srbije na reprezentativnom uzorku mikro i malih poduzeća širokog raspona poslovanja. Ustanovilo se da je pomoć tržišta prevladavajuća strategija u razvoju novog proizvoda, čije je obilježje uska suradnja s kupcima od ideje do finalnog proizvoda uključujući aktivnosti istraživanja i razvoja (R\&D - research and development). Pored kupaca, glavni izvori ideja su konkurenti i sajmovi ili izložbe. Marketinške aktivnosti povezane s predstavljanjem novog proizvoda sasvim su ograničene. Te su se spoznaje usporedile s načinima razvoja novog proizvoda u susjednim zemljama. Na temelju naših spoznaja predlažemo dvije mjere za poboljšanje razvoja novog proizvoda u malim proizvodnim poduzećima u Srbiji: uspostaviti jaču suradnju s vanjskim centrima znanja (sveučilišta, istraživački instituti, centri inovacija) te izgraditi mreže inovacija s komplementarnim partnerima aktivno primjenjujući koncept otvorene inovacije.

Ključne riječi: izvori ideja; mikro i mala poduzeća; otvorena inovacija; razvoj novoga proizvoda

\section{Introduction}

Small manufacturing enterprises are considered major growth engines of economies in transition. Although high-tech enterprises take much of the spotlight, most of the manufacturing firms worldwide belong to the lowtech and medium-low-tech (LMT) industrial segment. Based on the OECD classification, LMT industrial sectors are characterized with R\&D intensity below 3 percent and incorporate mature industries, such as the food industry, the paper, publishing and print industry, the wood and furniture industry, the production of household appliances, and the production of metal products. LMT enterprises are important for employment, economic growth and knowledge formation [1]. Low-tech and medium-low tech enterprises represented $53 \%$ and $35 \%$ of the total number of enterprises in EU countries, respectively [2]. On the other hand, technological structure of enterprises in Serbia is given by the following relationship: $65 \%$ low-tech and $25 \%$ medium-low-tech enterprises [3], which is similar to the EU countries. Urošević and Stamatović [4] report that small and micro enterprises (SME) in Serbia represent $99,8 \%$ of the total number of enterprises, $65,5 \%$ of employment, $67,6 \%$ of turnover, and about $36 \%$ of gross domestic product. Micro enterprises dominate in the SME segment with 93,5\% share [5].

New product development is generally considered a critical factor in ensuring continuous growth and survival of SMEs. SMEs generally implement closed strategies for new product development. The major risk of such strategies is inability to identify and pursue any business opportunity outside the present product scope. Successful new product development requires strong interactions with customers through sales, marketing and product design activities in order to clearly understand changes in customer needs. In addition, SMEs in more developed economies often integrate suppliers in the new product development through joint education and training activities, feasibility studies, set up of common performance goals and product design assessment [6].

Over the last 25 years Serbian economy suffered enormously as a result of violent disintegration of Yugoslavia and inefficient privatization during early stages of transition, which had major effects on the local SME operations and practices. Research describing new product development in Serbian SMEs has not been much covered in literature. Just a few references can be found, but their focus is new product development in high-tech SMEs which covers a minor fraction of manufacturing enterprises in Serbia [7].

In this paper we present our research on new product development in manufacturing Serbian SMEs and compare our findings with practices in neighboring and more developed countries. We further discuss major drawbacks of new product development in Serbian SMEs and provide recommendations to improve this process.

\section{Serbia in comparison with neighbouring countries}

Over the last 50 years Serbian economy went through three distinct periods [3]:

1. Industrialization and technical expansion (from 1960 to 1990) characterized by stable technological development and dynamic industrial growth $(7,8 \%$ per annum),

2. Disintegration of Yugoslavia (from 1991 to 2000) through wars, hyperinflation and international 
sanctions, characterized by production fragmentation, loss of supply chain and markets, and

3. Deindustrialization (from 2001 to the present days) characterized by incomplete transition, poor privatization process, and loss of human, infrastructure and program resources.

As a result of these challenging times, technologies utilized in Serbian enterprises became obsolete with largely depreciated industrial equipment. The average age of equipment in Serbian enterprises is 30 years, while the current state of the economic development follows EU with a lag of 29,5 years [5].

Serbian enterprises make products and services which often do not meet international quality standards and are generally characterized by low productivity and poor capacity utilization.

In the period from 2003 to 2010 , competitiveness of the Serbian economy has fallen from $77^{\text {th }}$ to $96^{\text {th }}$ place among 139 national economies. As Tab. 1 shows, Serbia compares rather poorly with neighboring states.

Table 1 Ranking of the Western Balkans in terms of competitiveness in 2010

\begin{tabular}{|l|c|}
\hline \multicolumn{1}{|c|}{ Country } & Position \\
\hline Slovenia & 45 \\
\hline Montenegro & 48 \\
\hline Croatia & 77 \\
\hline F.Y. R. Macedonia & 79 \\
\hline Serbia & 96 \\
\hline Bosnia and Herzegovina & 102 \\
\hline The source: [8]
\end{tabular}

In addition to the problems related to the destruction of the industrial infrastructure mentioned above, manufacturing SMEs in Serbia have other barriers for growth.

Table 2 Barriers for growth of manufacturing SMEs in Serbia in comparison with neighboring countries

\begin{tabular}{|c|c|c|c|c|c|}
\hline \multirow{3}{*}{ Barriers } & \multicolumn{5}{|c|}{ Country } \\
\hline & \multicolumn{4}{|c|}{ EU member } & \multirow{2}{*}{$\frac{\text { In transition }}{\text { Serbia }^{5)}}$} \\
\hline & Czech $^{1)}$ & Slovenia $^{2)}$ & Romania $^{3)}$ & Greece $^{4)}$ & \\
\hline Company registration & $\bullet$ & $\bullet$ & $\bullet$ & $\bullet$ & $\bullet$ \\
\hline Corruption & $\bullet$ & $\bullet$ & $\bullet$ & $\bullet$ & $\bullet$ \\
\hline Credit conditions & $\bullet$ & $\bullet$ & $\bullet$ & $\bullet$ & $\bullet$ \\
\hline Taxes & $\bullet$ & & & & $\bullet$ \\
\hline Qualified labor & $\bullet$ & $\bullet$ & $\bullet$ & $\bullet$ & $\bullet$ \\
\hline Training & & & $\bullet$ & $\bullet$ & $\bullet$ \\
\hline Imports and exports & & & $\bullet$ & $\bullet$ & $\bullet$ \\
\hline Purchasing power & & & $\bullet$ & $\bullet$ & $\bullet$ \\
\hline Attracting investments & & & $\bullet$ & $\bullet$ & $\bullet$ \\
\hline Cooperation with universities & & & $\bullet$ & & $\bullet$ \\
\hline Resources & & & & & $\bullet$ \\
\hline
\end{tabular}

Tab. 2 presents an overview of these barriers for Serbia compared to the neighboring countries. The major barriers are: slow procedures for business registration, high level of corruption, adverse credit conditions, high taxes, lack of qualified labor, lack of training in the field of management and new technologies, drop in imports and exports, weak purchasing power of the population, poor efficiency in attracting investment from EU funds, poor cooperation between the universities and enterprises, and lack of resources [9]. The table shows barriers for growth of manufacturing SMEs in Serbia in comparison with neighboring countries.

The macroeconomic constraints mentioned above created a challenging environment for industrial enterprises in Serbia. In the following sections we present our research on new product development practices in manufacturing Serbian SMEs.

Table 3 Manufacturing enterprises in Serbia covered by this research Business area

\begin{tabular}{|l|c|}
\multicolumn{1}{|c|}{ Business area } & Number of respondents \\
\hline The production of machines and devices, The production of electric and fiber devices & 16 \\
\hline The production of chemicals, chemical products and artificial and synthetic fibers & 16 \\
\hline The production of rubber products and product made from plastic mass & 14 \\
\hline The production of basic metals and standard metal products & 12 \\
\hline Wood processing and products made from wood & 8 \\
\hline The production of food products & 2 \\
\hline The production of textiles and textile products & 2 \\
\hline The production of leather and objects made from leather & 2 \\
\hline Publishing and printing & 2 \\
\hline The production of products made from other non-metal minerals & 2 \\
\hline
\end{tabular}

\section{Research methodology}

This research covered 76 small manufacturing enterprises including $48 \mathrm{MEs}$ and 28 SEs. The questionnaires were completed by managers, their deputies, or other company representatives. As Tab. 3 shows, the research sample included primarily low-and 
medium-tech enterprises representing a broad range of businesses.

The questions were focused on the new product development practices in these enterprises. The results were initially analyzed using descriptive statistics. The Chi-Square test was also used to investigate if new product development practices in MEs compared to SEs are different.

The value of $p<0,05$ was taken to indicate statistical significance for rejecting the null hypothesis of homogeneity between ME and SE categories.

\section{Results and discussion}

Based on the results of this research, SMEs in Serbia work very closely with their customers on new product development. Around $69 \%$ of the SMEs use some form of a market pull strategy, while only $18 \%$ respondents described their approach as a technology push strategy. Supporting these results is the fact that all SMEs had experience with custom manufacturing, i.e. making products based on customer documentation and specifications. Around $83 \%$ of the SMEs directly combine their research activities with those of their customers.

Manufacturing SMEs can use pull marketing to raise awareness about a product before it becomes available for purchase. Market pull strategy relies on the necessity of respecting the market and customer needs. It is a marketoriented approach, where the technology is considered to be of less importance. The essence of this strategy is to "identify the needs of customers", and then launch projects to develop new technologies [15].

The most prevalent sources of ideas for new product development are customers, competitors and trade fairs or exhibitions. Table 4 compares our results with findings reported for some neighboring transitional economies. In comparison with Serbia, Austria and Slovenia have similar results with a distinction that the cooperation with suppliers is more pronounced in these countries than in Serbia.

In Croatia the results are somewhat different; i.e. most ideas for a new product are obtained from employees. It was also found that ideas practically never come from universities or research institutes, which illustrates low impact of broader scientific and technical community on industrial development in Serbia. Contrary to SME practices in Serbia, $20 \%$ of ideas for new product development come from universities or research institutes in Austria [16], and about $7 \%$ in Croatia [17]. Similar results were obtained for Slovenia where SMEs collaborate to some extent with government, public research institutes and universities in new product development [18].

Table 4 The sources of ideas for new product development in Serbia and some neighbors

\begin{tabular}{|c|c|c|c|c|}
\hline \multirow{2}{*}{ Sources of ideas } & \multicolumn{4}{|c|}{ Country / \% } \\
\hline & Serbia $^{1)}$ & Austria [14] & Slovenia [12] & Croatia [18] \\
\hline Customers & 29 & 21,4 & 41 & 30 \\
\hline Competitors & 27 & 33,6 & 22 & 4 \\
\hline Fairs and exhibitions & 20 & 1 & 25 & 1 \\
\hline Suppliers & 6 & 17,9 & 25 & 17 \\
\hline Employees & 11 & 1 & 1 & 36 \\
\hline
\end{tabular}

The sources of ideas for SMEs may be internal or external. Varis and Littunen [19] include to internal sources know-how of the firm, educational events for employees, organization of work, initiatives from employees, organized communication in the firm. External sources of ideas are also of great significance and originate from the market, which includes customers, suppliers, competitors, sales and delivery organizations, business service firms and consultants, universities and research institutes, local technology centers and business incubators, exhibitions, fairs, internet, media, professional literature, educational meetings, participation in development projects [19]. In developed economies, such as the UK, internal factors are present $28 \%$, while external factors are as follows: suppliers $16 \%$, customers or clients $16 \%$, competitors $6 \%$ [20]. The ideas from the universities and research institutes are represented by only $5 \%$.

Our research shows that internal $R \& D$ plays a significant role in new product development in Serbia, since $84 \%$ of respondents reported these activities. This percentage is significantly higher for SEs (93\%) than for MEs (78\%). Only a small part of these R\&D activities could be considered innovative while a majority represents product testing or technical services.
Around $92 \%$ of respondents were directly involved in new product development in their SMEs. Buying new technologies (42\%) and buying technical solutions (40 $\%$ ) related to new product development were considered most important for improving business activities of SMEs. However, only $35 \%$ of SMEs were involved in any project financing activities coming from domestic or international sources. The major barriers for improving the new product development process were lack of financial resources $(58 \%)$ and institutional barriers (42 $\%)$.

SMEs in Serbia belong to the group of modest innovators: 3,5\% of SMEs performed innovative research activities, while $19 \%$ were involved in an innovative network of cooperation with other enterprises [21]. However, one should emphasize that Serbia ranks $7^{\text {th }}$ on the global innovation efficiency index, which can be considered quite high. The quoted reference attempts to compare innovation efficiencies of countries belonging to various income groups. Innovation efficiency index is a ratio of innovation output sub-index (knowledge, technology and creative outputs) and innovation input sub-index (institutions, human capital and research, infrastructure, market and business sophistication). Since Serbia invests very modest amounts in innovation, its 
innovation efficiency is proportionally very high. Relative advantages of Serbia are human resources and research system, while the drawbacks are reflected in the absence of industrial enterprises in financing and conducting $\mathrm{R} \& \mathrm{D}$, poor institutions and political instability [22].

As a comparison with neighboring countries, about $17 \%$ of all Slovenian companies with domestic capital can be considered innovative [23]. There is also a regional R\&D cooperation and collaboration with foreign enterprises leading to increased productivity and growth [24]. Only $19 \%$ of SMEs in Romania were involved in innovation activities focused on new products (37\%), new technologies (29\%), managerial and marketing activities $(24 \%)$, and human resources training (13\%) [25].

According to the results of our research, marketing activities related to new products are quite limited. In a majority of cases marketing was non-existent $(21 \%)$ or conducted with a low level of advertising (46\%). Only 33 $\%$ of respondents reported marketing strategies involving more significant advertising expenses. Most of the enterprises presented new products at trade fairs or exhibitions (67\%), however, the percentage was significantly higher for SEs (79\%) than for MEs (59\%). Only a small fraction of SMEs (22\%) used trade journals or other technical publications to report R\&D work related to new product development. This percentage was significantly higher for SEs (43\%) than for MEs (9\%).

Fairs and exhibitions help enterprises in promoting their products. They represent a reliable medium for information sharing. Participation in fairs and exhibitions enables creation of new commercial agreements, meeting competition, potentially increasing the number of customers, and entering new markets. For SMEs in Slovenia, product presentation is mainly through fairs and exhibitions (83\%) and magazines (75 \%) [26]. In Romania, $70 \%$ of companies have participated in fairs and exhibitions at national levels, but only $30 \%$ attended international fairs, which suggests relatively low effectiveness of promotional techniques [27].

\section{Recommendation for Improving NPD}

According to the survey conducted by Venckuviene [28], low-tech concept is characterized by relatively mature enterprises, high percentage of low-skilled workers, manufacturing of standard products, low business risks, relatively broad market, low R\&D costs, and superficial internal scientific knowledge. HirschKreinsen et al. [29] point out that the lack of scientific and technical knowledge within low-tech enterprises can be compensated with high-quality skills developed through practice and continual learning at work.

However, low-tech enterprises can easily abandon strictly defined distribution of work, assignments of tasks and labor qualifications. As a result, low-tech concept provides the flexibility to reorganize the enterprise with an emphasis on the specific knowledge generation, which increases productivity and quality in the production process.

Manufacturing SMEs cannot rely on their internal strength and internal knowledge, but they rather look for solutions coming from outside. New product development includes the creation of prototypes, as well as research and testing. In this regard, SMEs would certainly benefit from cooperation with universities or research institutes.

According to Schartinger et al. [30], universities play a key role in knowledge transfer to enterprises. Their impact is reflected in joint collaboration on research projects, research financed by enterprises through contract funding, continuing staff education, and involvement of academic researchers as consultants to private enterprises. Considering the low level of cooperation with universities and research institutes shown in our research, Serbian SMEs should definitely improve activities to acquire technology, resources and knowledge from external sources. Serbia should make a strategic collaboration with the neighboring countries, which could lead to an increased character of innovative activity.

This strategy includes cooperation with knowledge centers such as professional consultants, university researchers, technology and innovation centers. Efficient innovation process applied to new product development involves the effective use of external sources of knowledge, better exploitation of internal knowledge and intellectual property [31]. On the other hand, Serbian SMEs are generally unaware of the risks of the confidential information exchange within this type of strategy and additional activities would be required to generate that knowledge.

Developing strong relationships with partners having different capabilities can significantly improve new product development in LMT enterprises. It is important that the partners recognize their specific capabilities and integrate into innovation networks which are based on partner coordination in the area of product development and manufacture. This type of networks leads to an open innovation concept which is defined as "...the use of purposive inflows and outflows of knowledge to accelerate internal innovation, and expand the markets for external use of innovation, respectively" [32].

SMEs in low-tech industries in developed countries have proven capable to use and integrate knowledge from external partners for new product development. An innovation survey of small LMT enterprises in Belgium has demonstrated relatively high open innovation intensity, which has been defined as the number of collaborative deals divided by the number of employees [33].

Open innovation is not necessarily linked to technology. In fact, selecting a proper business model is most important for unlocking the latent value of the new or existing technologies. There are numerous examples of using an innovative business model to avoid the commodity trap, which has become a major threat to the growth of small LMT enterprises with an emergence of low-cost producers such as those from China. The open innovation concept has been known for quite some time as a valid strategy to increase competitiveness of small enterprises and increase their innovation capacity. Sometimes, the open innovation strategy creates a new form of organization; the larger enterprise with most resources takes complete control over sales and marketing activities, while the smaller enterprise becomes an OEM supplier which manufactures the new product using its own technology [34]. 
The ideas and possible applications of open innovation in developing countries are rarely researched. SMEs in developing countries do not have the research centers and contacts with multinational corporations which are generators of open innovation [35]. According to the same source, an efficient open innovation strategy requires significant involvement of the government in building an infrastructure and communication network between SMEs with emphasis on the market needs.

\section{Conclusion}

Small manufacturing enterprises in Serbia generally use market pull as a dominant strategy for new product development. This approach is characterized by close collaboration with customers in all steps of the development process, including joint R\&D activities. The most prevalent sources of ideas for new product development in Serbia are customers, competitors and trade fairs or exhibitions. Ideas practically never come from universities or research institutes, which shows a low impact of broader scientific and technical community on industrial development in Serbia. The results are similar to neighboring countries, such as Slovenia and Austria, which have a somewhat higher involvement of external knowledge centers in idea generation.

Marketing activities related to new product introduction were found to be quite limited, either nonexistent or conducted with a low level of advertising. The main channels for advertising new products are trade fairs or exhibitions, while only a small fraction of SMEs uses trade journals or other technical publications to report R\&D work related to new product development. These findings are similar to neighboring countries, such as Slovenia and Romania.

We recommend two strategies to improve new product development in small manufacturing enterprises in Serbia. Manufacturing SMEs need to establish a closer cooperation with external knowledge centers, such as universities, research institutes and innovation centers, through collaboration at national, regional and interregional level. They would also strongly benefit by establishing innovation networks with complementary partners, which would utilize some form of the open innovation concept.

\section{Acknowledgement}

This paper is a result of the project TR32008 supported by the Serbian Ministry of Education, Science and Technological Development.

\section{References}

[1] Hirsch-Kreinsen, H. Low-technology: a forgotten sector in innovation policy. // Journal of technology management \& innovation. 3, 3(2008), pp. 11-20. DOI: 10.4067/S071827242008000100002

[2] Annual Report on European SMEs 2012/2013, URL: http://ec.europa.eu/enterprise/policies/sme/facts-figuresanalysis/performance-review/files/supporting-documents/ 2013/annual-report-smes-2013_en.pdf./.(10.3. 2014)

[3] Petrović, P. B. Industrialization-Quantitative Framework, Technological Dimension and the Future we cannot ignore.
// Management. 70, (2014), pp. 27-58. DOI: 10.7595/management.fon.2014.0006

[4] Urošević, S.; Stamatović, M. Role of Small and MediumSized Enterprises in the Enhancement of the Serbian Textile Industry in Times of Crisis. // Fibres \& Textiles in Eastern Europe. 19, 4(2011), pp. 14-19.

[5] Djordjevic, D.; Cockalo, D.; Sajfert, Z.; Bogetic, S.; Klarin, M. Competitive abilities and students entrepreneurial behaviour: The research results from Serbia. // African Journal of Business Management. 5, 26(2011), pp. 1087810884. DOI: 10.5897/AJBM11.385

[6] Petersen, K. J.; Handfield, R. B.; Ragatz, G. L. A Model of Supplier Integration into New Product Development. //. Journal of Product Innovation Management. 20, 4(2003), pp. 284-299. DOI: 10.1111/1540-5885.00028

[7] Bošković, G. The necessity of the export-oriented reindustrialization strategy of Serbia, // Economic. 49, 2(2011), pp. 233-247.

[8] Schwab, K. The global competitiveness report 2010-2011. // Geneva: World Economic Forum. The web version (2010) URL: http://www3.weforum.org/docs/ WEF_GlobalCompetitivenessReport_2010-11.pdf (10. 3. 2014)

[9] Freel, M. S. Barriers to product innovation in small manufacturing firms. // International Small Business Journal. 18, 2(2000), pp. 60-80. DOl: $10.1177 / 0266242600182003$

[10] Bohata, M.; Mladek, J. The development of the Czech SME sector. // Journal of Business Venturing. 14, 5(1999), pp. 461-473. DOI: 10.1016/S0883-9026(98)00025-1

[11] Bartlett, W.; Bukvič, V. Barriers to SME growth in Slovenia. MOST: // Economic Policy in Transitional Economies. 11, 2(2001), pp. 177-195. DOI: 10.1023/A:1012206414785

[12] Constantin, D. L. SMEs, territorial development and networking: the case of Romania. // The CD-ROM Collection of Papers of the $42^{\text {nd }}$ Congress of the European Regional Association. / Dortmund, 2002.

[13] Voulgaris, F.; Papadogonas, T.; Agiomirgianakis, G. Job creation and job destruction in Greek manufacturing. // Review of Development Economics. 9, 2(2005), pp. 289301. DOI: 10.1111/j.1467-9361.2005.00277.x

[14] Kontic, L.; Kontic, J.; Vidicki, D. Recovery strategies in Serbian mature companies. // African Journal of Business Management. 6, 36(2012), pp. 9906-9913. DOI: 10.5897/AJBM10.1621

[15] Brem, A.; Voigt, K. I. Integration of market pull and technology push in the corporate front end and innovation management-Insights from the German software industry. // Technovation. 29, 5(2009), 351-367. DOI: 10.1016/j.technovation.2008.06.003

[16] Kaufmann, A.; Tödtling, F. How effective is innovation support for SMEs? An analysis of the region of Upper Austria. // Technovation. 22, 3(2002), pp. 147-159. DOI: 10.1016/S0166-4972(00)00081-X

[17] Radas, S. Inovation Development in Leading Croatian Enterprises: Review of the Most Important Findings. // Croatian Economic Survey. 7(2005), pp. 167-192.

[18] Hojnik, B. B. Characteristics of Innovations in Companies: Comparison of Croatia and Slovenia. // China-USA Business Review. (2013), pp. 494-504.

[19] Varis, M.; Littunen, H. Types of innovation, sources of information and performance in entrepreneurial SMEs. // European Journal of Innovation Management. 13, 2(2010), pp.128-154. DOI: 10.1108/14601061011040221

[20] Laursen, K.; Salter, A. Searching high and low: what types of firms use universities as a source of innovation? // Research policy. 33, 8(2004), pp. 1201-1215. DOI: 10.1016/j.respol.2004.07.004 
[21] Hadzic, M.; Pavlovic, P. Serbian Small and Medium-sized Enterprises in Times of Crisis. // Acta Polytechnica Hungarica. 9, 3(2012), pp. 45-64.

[22] Schwab, K.; Sala-i-Martin, X. The global competitiveness report 2011-2012. // Geneva: World Economic Forum. The Web version (2011) URL: http://www3.weforum.org/docs/WEF_GCR_Report_201112.pdf (10. 3. 2014).

[23] Damijan, J. P.; Jaklic, A.; Rojec, M. Do external knowledge spillovers induce firms' innovations? Evidence from Slovenia. // LICOS Centre for Institutions and Economic Performance Discussion Paper. 2005, pp. 1-36. DOl: $10.2139 /$ ssrn.881522

[24] Jaklic, A.; Damijan, J. P.; Rojec, M. Innovation cooperation and innovation activity of Slovenian enterprises. // LICOS Centre for Institutions and Economic Performance Discussion Paper. 2008, pp. 1-23. DOI: 10.2139/ssrn.1107204

[25] Mioara, P. D.; Ofelia, R. V.; Victor, V.; Stegaroiu, I.; Gabriela, P.; Dumitru, G. Innovation Management and Romanian SME's. // Proceedings of the 4th WSEAS International Conference on Business Administration. (2010), pp. 149-153.

[26] Koschatzky, K.; Bross, U.; Stanovnik, P. Development and innovation potential in the Slovene manufacturing industry: analysis of an industrial innovation survey. // Technovation. 21, 5(2001), pp. 311-324. DOI: 10.1016/S0166-4972(00)00050$X$

[27] Dindire, L. L.; Gănescu, L. C. Analysis of Business Promotion Systems Implementation within Exporting Romanian Companies. // Annals of University of CraiovaEconomic Sciences Series. 3, 38(2010), pp. 1-12.

[28] Venckuviene, V. Challenges for Reaching Innovativeness in Lithuanian Low-Tech Sector: Case Study. // Economics and Management. 19, 2(2014), pp. 154-161. DOI: 10.5755/j01.em.19.2.6966

[29] Hirsch-Kreinsen, H.; Jacobson, D.; Laestadius, S.; Smith, $\mathrm{K}$. Low-tech industries and the knowledge economy: state of the art and research challenges. // SINTEF STEP Group. 2003.

[30] Schartinger, D.; Rammer, C.; Fischer, M. M.; Fröhlich, J. Knowledge interactions between universities and industry in Austria: sectoral patterns and determinants. // Research policy. 31, 3(2002), pp. 303-328. DOI: 10.1016/S00487333(01)00111-1

[31] Chesbrough, H.; Crowther, A. K. Beyond high tech: early adopters of open innovation in other industries. // R\&D Management. 36, 3(2006), pp. 229-236. DOI: 10.1111/j.14679310.2006.00428.x

[32] Chesbrough, H.; Vanhaverbeke, W.; West, J. Open innovation: Researching a new paradigm. Oxford university press, 2006.

[33] Vanhaverbeke, W. The benefits of open innovation in low tech SMEs: The quilts of Denmark story. // Innovation Management Magazine, (2011), pp. 1-16.

[34] Singh, R. K.; Garg, S. K.; Deshmukh, S. G. Strategy development by SMEs for competitiveness: a review. // Benchmarking: An International Journal. 15, 5(2008), pp. 525-547. DOI: 10.1108/14635770810903132

[35] Vrgovic, P.; Vidicki, P.; Glassman, B.; Walton, A. Open innovation for SMEs in developing countries-An intermediated communication network model for collaboration beyond obstacles. // Innovation. 14, 3(2012), pp. 290-302. DOI: 10.5172/impp.2012.14.3.290

\section{Authors' addresses}

Miloš Vorkapić

University of Belgrade, Institute of Chemistry, Technology and Metallurgy (ICTM) - Center of Microelectronic Technologies Njegoševa 12,11000 Belgrade, Serbia

E-mail: worcky@nanosys.ihtm.bg.ac.rs

Filip Radovanović

University of Belgrade, Institute of Chemistry, Technology and Metallurgy (ICTM) - Center of Microelectronic Technologies Njegoševa 12, 11000 Belgrade, Serbia

E-mail: filip@nanosys.ihtm.bg.ac.rs

Dragan Ćóckalo

University of Novi Sad, Technical faculty "Mihajlo Pupin" Zrenjanin, Đure Đakovića bb, 23000 Zrenjanin, Serbia

E-mail: dragan.cockalo@tfzr.rs

Dejan Đorđević

University of Novi Sad, Technical faculty "Mihajlo Pupin" Zrenjanin, Đure Đakovića bb, 23000 Zrenjanin, Serbia E-mail: dejan.djordjevic@tfzr.rs 